\title{
PENGARUH PERPUTARAN PIUTANG, PERPUTARAN PERSEDIAAN, DAN RASIO LANCAR TEHADAP PROFITABILITAS PERUSAHAAN MANUFAKTUR SEKTOR INDUSTRI BARANG KONSUMSI YANG TERDAFTAR DI BURSA EFEK INDONESIA PERIODE 2013-2015
}

\author{
Rita Satria ${ }^{1)}$ \\ 1) dosen universitas pamulang, email : ritasatria71@gmail.com
}

\section{ARTICLES}

INFORMATION

\section{JURNAL PIUTANG}

(Saham, Ekonomi, Keuangan dan Investasi )

Vol.2, No.1, September 2018

Halaman : $138-146$

(c) LPPM \& Prodi Manajemen

UNVERSITAS PAMULANG

$$
\begin{array}{ll}
\text { ISSN (online) } & : 2581-2777 \\
\text { ISSN (print) } & : 2581-2696
\end{array}
$$

\section{Keyword :}

Perputaran Piutang (RTO), Perputaran Persediaan (ITO), Rasio Lancar (CR), dan Return On Assets (ROA

JEL. classification :

C33, G20, G23, N65

\section{Contact Author :}

PRODI MANAJEMEN UNPAM

JL.Surya Kencana No.1 Pamulang

Tangerang Selatan - Banten

Telp. (021) 7412566, Fax (021) 7412491

Email :

jurnalfinance.unpam@gmail.com
Metode analisis dalam penelitian ini adalah uji deskriptif, asumsi klasik, regresi linear berganda, koefisien determinasi, uji $f$ dan uji t. Dari hasil penelitian ini dapat disimpulkan bahwa : (1) Perputaran piutang berpengaruh positif dan tidak signifikan terhadap profitabilitas, (2) Perputaran persediaan berpengaruh positif dan signifikan terhadap profitabilitas, (3) Rasio lancar berpengaruh positif dan tidak signifikan terhadap profitabilitas.

The method of analysis in this research is descriptive test, classical assumption (normality test), multiple linear regression, coefficient of determination, $F$ test and $T$ test. From the results of this study, it can be concluded that: (1) Receivable turnover has positive and no significant effect on profitability, (2) Inventory turnover has positive and significant effect on profitability, (3) Current ratio has positive and no significant effect on profitability. 


\section{A. Pendahuluan}

Berbagai penelitian yang terkait dengan perputaran piutang, perpuataran persediaan, dan rasio lancar terhadap profitabilitas perusahaan menunjukkan keanekaragaman hasil. Seperti penelitian yang dilakukan Sufiana dan Purnawati (2013) menunjukkan bahwa perputaran piutang berpengaruh positif terhadap profitabilitas perusahaan. Namun penelitian ini tidak sejalan dengan yang dilakukan oleh Suarnami, Suwendra, dan Cipta (2014) dan penelitian Rahayu Susilowibowo (2014) menunjukkan bahwa perputaran piutang tidak berpengaruh signifikan terhadap profitabilitas.

Untuk perputaran persediaan, penelitian yang dilakukan oleh Sufiana dan Purnawati (2013) menunjukkan bahwa perputaran persediaan berpengaruh positif dan signifikan terhadap profitabilitas perusahaan. Penelitian Rahayu (2014) menunjukkan perputaran persediaan berpengaruh positif dan signifikan terhadap profitabilitas perusahaan. Penelitian ini berbanding terbalik dengan yang dilakukan oleh Sari (2014) dan Putra (2012) menunjukkan bahwa perputaran piutang tidak berpengaruh terhadap profitabilitas perusahaan.

Penelitian mengenai rasio lancar yang dilakukan oleh Wijaya (2012) menunjukkan bahwa komponen working capital berupa rasio lancar berpengaruh positif dan signifikan terhadap profitabilitas perusahaa. Penelitian ini bertentangan dengan penelitian yang dilakukan Puty dan Erawati (2013) menunjukkan bahwa rasio lancar tidak berpengaruh terhadap profitabilitas. Penelitian yang sama dilakukan oleh Agha (2014) menunjukkan bahwa rasio lancar tidak berpengaruh terhadap profitabilitas perusahaan.

\section{B. Perumusan Masalah}

1. Apakah perputaran piutang berpengaruh terhadap profitabilitas pada perusahaan manufaktur sektor industri barang konsumsi yang terdaftar di BEI periode 20132015 ?

2. Apakah perputaran persediaan berpengaruh terhadap profitabilitas pada perusahaan manufaktur sektor industri barang konsumsi yang terdaftar di BEI periode 2013-2015?

3. Apakah rasio lancar berpengaruh terhadap profitabilitas pada perusahaan manufaktur sektor industri barang konsumsi yang terdaftar di BEI periode 20132015 ?

\section{Tujuan Penelitian}

1. Untuk mengetahui pengaruh perputaran piutang terhadap profitabilitas pada perusahaan manufaktur sektor industri barang konsumsi yang terdaftar di Bursa Efek Indonesia (BEI) periode 2013-2015.

2. Untuk mengetahui pengaruh perputaran persediaan terhadap profitabilitas pada perusahaan manufaktur sektor industri barang konsumsi yang terdaftar di Bursa Efek Indonesia (BEI) periode 2013-2015.

3. Untuk mengetahui pengaruh rasio lancar terhadap profitabilitas pada perusahaan manufaktur sektor industri barang konsumsi yang terdaftar di Bursa Efek Indonesia (BEI) periode 2013-2015. 


\section{Landasan Teori}

\section{Pengertian Modal}

Menurut Brigham (2006: 62) "Modal adalah jumlah dari utang jangka panjang, saham preferen, dan ekuitas saham biasa, atau pos-pos tersebut dan utang jangka pendek yang dikenakan bunga". Definisi modal dalam Standar Akuntansi Keuangan (IAI, 2007:9) "Modal adalah hak residual atas asset perusahaan setelah dikurangi semua kewajiban".

\section{Pengertian Modal}

Menurut Sri Dwi Ari Ambarwati (2010:112), yaitu: “Modal kerja adalah modal yang seharusnya tetap ada dalam perusahaan sehingga operasional perusahaan menjadi lebih lancar serta tujuan akhir perusahaan untuk menghasilkan laba akan tercapai."

\section{Sumber Modal Kerja}

Menurut Munawir (2004), pada dasarnya modal kerja (working capital) terdiri dari dua bagian pokok, yaitu :

a. Bagian yang tetap atau bagian yang permanen, yaitu jumlah minimum yang harus tersedia agar perusahaan dapat berjalan dengan lancar tanpa kesulitan keuangan.

b. Jumlah modal kerja variabel yang jumlahnya tergantung pada aktivitas musiman dan kebutuhan-kebutuhan di luar aktivitas biasa. Kebutuhan modal kerja yang permanen seharusnya atau sebaiknya dibiayai oleh pemilik perusahaan atau para pemegang saham.

\section{Perputaran Piutang}

Dengan menghitung tingkat perputaran piutang (receivable turnover) dapat menilai posisi piutang dan taksiran waktu pengumpulannya yaitu dengan membagi total penjualan kredit (neto) dengan rata-rata piutang. Semakin cepat syarat pembayaran kredit berarti semakin cepat terikatnya modal kerja tersebut dalam piutang dan berarti semakin besar tingkat perputaran piutang usaha dalam satu periode dan begitu pula sebaliknya.

Hal tersebut juga sejalan dengan pernyataan Murhadi (2013:58) yaitu makin tinggi receivable turnover, mengindikasikan bahwa investasi yang ditanamkan dalam bentuk piutang adalah rendah, sebaliknya bila receivable turnover rendah menunjukkan bahwa perusahaan terlalu banyak atau terlalu longgar dalam pemberian piutang kepada pelanggan.

Rumus untuk mencari perputaran piutang (receivable turn over) adalah sebagai berikut :

$$
\text { Perputaran Piutang }=\frac{\text { Penjualan Bersih }}{\text { Rata }- \text { rata Piutang }}
$$

Demikian dapat disimpulkan bahwa perputaran piutang merupakan rasio yang digunakan untuk menilai dan mengukur berapa kali piutang berputar dalam satu periode sejak terjadinya piutang sampai piutang tertagih kembali menjadi kas dalam perusahaan dan menunjukkan berapa lama waktu yang digunakan untuk menagih piutang. Semakin besar perputaran piutang semakin baik kondisi perusahaan karena penagihan piutang dilakukan dengan cepat dan sebaliknya 


\section{Perputaran Persediaan}

Menurut Murhadi (2013:19), persediaan merupakan keseluruhan barang baik mulai dari bahan baku (raw material), barang setengah jadi (work in process) maupun barang jadi (finished good) yang masih ada diperusahaan dalam rangka proses bisnis perusahaan. Untuk perusahaan manfuaktur (yang memproduksi barang), maka persediaan yang dimiliki meliputi persediaan bahan mentah, persediaan barang dalam proses dan persediaan barang jadi.

Menurut Harrison Jr et.al. (2013), adapun rumus perputaran persediaan adalah sebagai berikut :

$$
\text { Perputaran Persediaan }=\frac{\text { Harga Pokok Penjualan }}{\text { Persediaan }}
$$

Demikian dapat disimpulkan bahwa perputaran persediaan merupakan rasio yang digunakan untuk menilai dan mengukur berapa kali persediaan berputar dalam satu periode. Semakin tinggi perputaran persediaan maka semakin baik bagi keadaan perusahaan, karena menunjukkan kinerja perusahaan berjalan secara efektif dan efisien serta produktif dalam penggunaan persediaan. Sebaliknya semakin rendah perputaran persediaan maka membuat kondisi perusahaan tidak baik, hal ini dikarenakan memperbesar kerugiaan yang diterima perusahaan akibat penurunan harga, penambahan biaya penyimpanan dan pemeliharaan persediaan.

\section{Rasio Lancar}

Dengan kata lain dapat disimpulkan bahwa rasio lancar adalah rasio yang menilai dan mengukur mampu tidaknya perusahaan dalam memenuhi atau membayar utang-utang jangka pendeknya pada saaat jatuh tempo. Adapun rumus yang digunakan untuk menghitung rasio lancar adalah sebagai berikut :

\section{Rasio Lancar $=\frac{\text { Aset Lancar }}{\text { Kewajiban Lancar }}$}

Menurut Harrison Jr et.al. (2013), data diolah kembali Jika rasio lancar rendah, maka perusahaan kurang modal untuk membayar semua kewajibannya, namun jika rasio lancar tinggi belum tentu keadaan perusahaan sedang baik.

\section{E. Metodologi}

Penelitian ini dilakukan pada perusahaan Manufaktur sektor industri barang konsumsi yang terdaftar di Bursa Efek Indonesia (BEI). Objek studi penelitian ini adalah 15 perusahaan manufaktur yang terdaftar di Bursa Efek Indonesia. Data yang digunakan dalam penelitian ini adalah data sekunder, yaitu data yang diperoleh dari pihak lain dalam bentuk sudah jadi dan telah dipublikasikan dalam bentuk laporan keuangan perusahaan. Laporan keuangan yang digunakan yaitu laporan keuangan tahun 2013-2015. Penelitian ini menggunakan metode regresi linier berganda.

\section{F. Hasil dan Pembahasan}

Metode analisis data yang digunakan dalam penelitian ini adalah metode statistik dengan menggunakan program SPSS versi 23.0.

\section{Uji Asumsi Klasik}

a. Uji Normalitas.

Dari hasil normal probability plot diatas dapat dilihat bahwa Sebaran titik-titik dari gambar Normal P-P Plot di atas relatif mendekati garis lurus. Hal seperti ini dapat disimpulkan bahwa data terdistribusi normal atau memenuhi asumsi klasik normalitas. 
Selanjutnya, uji normalitas juga dapat menggunakan uji statistik. Uji statistik yang digunakan untuk menguji normal residual yaitu dengan uji statistik nonparametrik Kolmogorov-Smirnov (K-S). Berikut adalah tabel dari uji Kolmogorov-Smirnov (K-S) :

Uji Normalitas dengan Kolmogorov-Smirnov

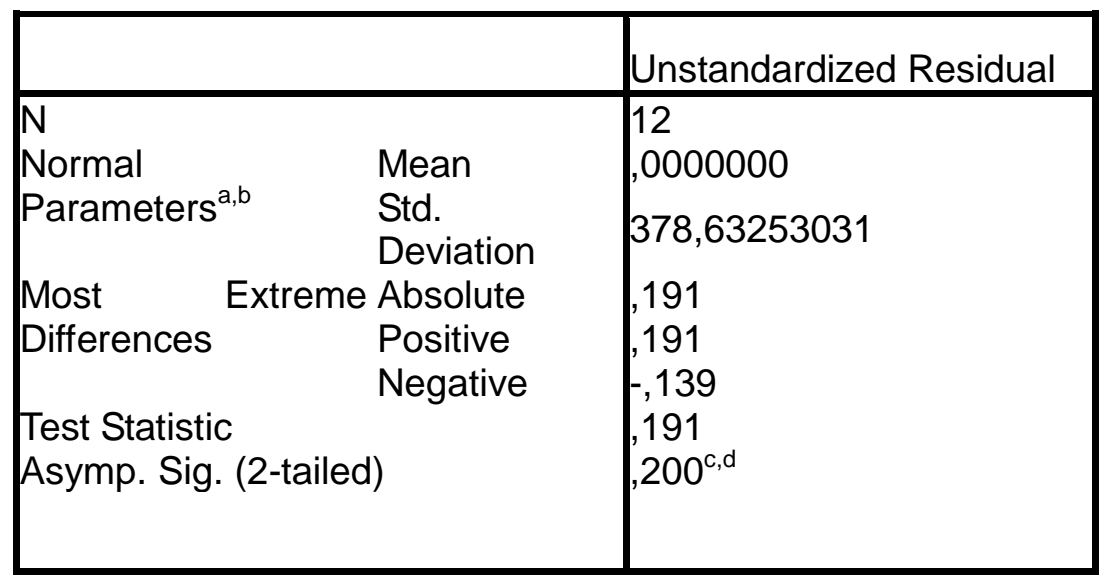

Sumber : Data diolah menggunakan SPSS 23, 2016.

Dari hasil uji One-Sample Kolmogorov-Smirnov Test diatas diperoleh nilai Asymp. Sig. (2-tailed) sebesar 0,200. Artinya bahwa nilai tersebut $0,200>0,05$ maka dapat disimpulkan bahwa data berdistribusi normal.

\section{b. Uji Multikolonieritas}

Menurut Imam Ghozali (2013:105) uji multikolonieritas bertujuan untuk menguji apakah model regresi ditemukan adanya korelasi antar variabel bebas (independen). Model regresi yang baik adalah tidak terjadi korelasi di antara variabel indipenden. Multikolonieritas dapat juga dilihat dari nilai tolerance dan lawannya variance inflation factor (VIF). Nilai cutoff yang umum dipakai untuk menunjukkan adanya multikolonieritas adalah nilai Tolerance $\leq 0,10$ atau sama dengan nilai VIF $\geq 10$. Berikut ini adalah hasil uji multikolonieritas:

\section{Uji Multikolonieritas}

\begin{tabular}{|ll|l|l|}
\hline \multirow{2}{*}{ Model } & \multicolumn{2}{|l|}{ Collinearity Statistics } \\
\cline { 3 - 4 } & Tolerance & VIF \\
\hline 1 & (Constant) & & \\
& EPS & 834 & 1,199 \\
DPS &, 834 & 1,199 \\
\hline
\end{tabular}

a. Dependent Variable: Harga_Saham

Dari hasil uji

multikolonieritas di atas, menunjukkan bahwa nilai Tolerance dari variabel EPS dan DPS sebesar 0,834 dan nilai VIF-nya sebesar 1,199. Karena nilai Torelance $>0,10$ dan nilai VIF-nya $<10$, maka dapat disimpulkan bahwa tidak terjadi multikolonieritas dalam model regresi. 


\section{c. Uji Autokorelasi}

Menurut Imam Ghozali (2013:110) uji autokorelasi bertujuan menguji apakah dalam model regresi linear ada korelasi antara kesalahan pengganggu pada periode $t$ dengan kesalahan pengganggu pada periode t-1 (sebelumnya). Untuk mendeteksi ada atau tidaknya autokorelasi menggunakan uji Durbin Watson (DW test). Berikut ini adalah hasil dari uji autokorelasi:

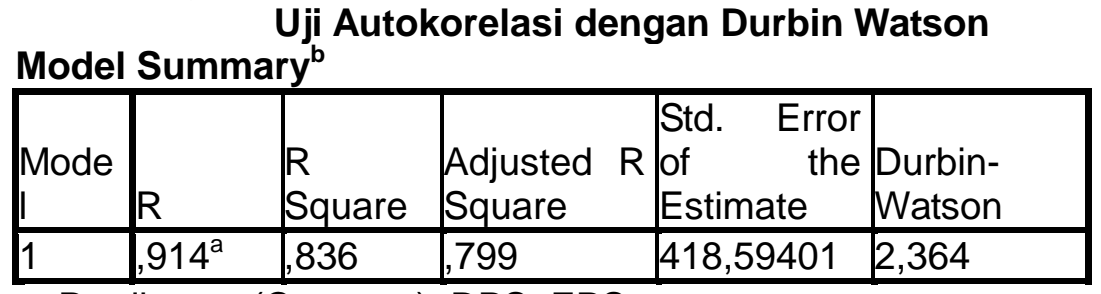

a. Predictors: (Constant), DPS, EPS

b. Dependent Variable: Harga_Saham

Sumber : Data diolah menggunakan SPSS 23, 2016.

Berdasarkan tabel 4.7 diatas dapat diketahui bahwa nilai Durbin Watson sebesar 2,364. Dari tabel Durbin Watson dengan tingkat signifikansi $5 \%$ dengan 10 data dan 2 variabel bebas, diketahui bahwa dl sebesar 0,799 dan du sebesar 1,641, $4-$ du (4 $1,641=2,364)$. Tampak bahwa nilai Durbin-Watson tersebut berada diantara $\mathrm{du}<\mathrm{d}<4-$ du $(1,641<2,064<2,364)$, maka dapat disimpulkan bahwa tidak ada autokorelasi positif atau negatif.

Untuk memperkuat hasil tersebut dapat digunakan dengan uji Run Test, di mana gangguan autokorelasi terjadi jika signifikansi di bawah 0,05. Berikut ini adalah hasil dari uji Run Test :

\section{Uji Autokorelasi dengan Run Test}

\begin{tabular}{|l|l|}
\hline & Unstandardized Residual \\
\hline Test Value & a \\
Cases < Test Value & $-49,12197$ \\
Cases >= Test Value & 6 \\
Total Cases & 12 \\
Number of Runs & 7 \\
Z &, 000 \\
Asymp. Sig. (2-tailed) & 1,000 \\
\hline
\end{tabular}

a. Median

Sumber : Data diolah menggunakan SPSS 23, 2016.

Berdasarkan tabel 4.8 diatas menunjukkan bahwa nilai test adalah $-49,12197$ dengan nilai signifikan $1,000(1,000>0,05)$ yang berarti hipotesis nol ditolak, sehingga dapat disimpulkan bahwa residual tidak random atau tidak terjadi autokorelasi antar nilai residual.

\section{d. Uji Heteroskedastisitas}

Menurut Imam Ghozali (2013:139) uji heteroskedastisitas bertujuan untuk menguji apakah dalam model regresi terjadi ketidaksamaan variance dari residual satu pengamatan ke pengamatan lain. Uji heteroskedastisitas yang dilakukan dengan menggunakan uji geljser. Untuk mengetahui adanya heteroskedastisitas yaitu dengan melihat signifikansi $5 \%$. Berikut adalah hasil uji heteroskedastisitas dengan menggunakan uji glejser: 


\section{Uji Heteroskedastisitas dengan Glejser}

Coefficients $^{\mathrm{a}}$

\begin{tabular}{|c|c|c|c|c|c|}
\hline \multirow[b]{2}{*}{ Model } & \multicolumn{2}{|c|}{$\begin{array}{l}\text { Unstandardized } \\
\text { Coefficients }\end{array}$} & \multirow{2}{*}{$\begin{array}{l}\text { Standardiz } \\
\text { ed } \\
\text { Coefficient } \\
\text { s } \\
\text { Beta } \\
\end{array}$} & \multirow[b]{2}{*}{$\mathrm{T}$} & \multirow[b]{2}{*}{ Sig. } \\
\hline & $B$ & Std. Error & & & \\
\hline (Constant) & 295,377 & 136,115 & & 2,170 & ,058 \\
\hline EPS &,- 394 &, 908 &,- 156 &,- 434 &, 675 \\
\hline DPS & 2,123 & 4,130 &, 184 &, 514 &, 620 \\
\hline
\end{tabular}

A. Dependent Variable: RES_2

Dari tabel uji glejser di atas diperoleh nilai signifikansi EPS $(0,675)$ dan DPS $(0,620)$ atau nilai signifikansi untuk semua variabel $>0,05$, sehingga dapat disimpulkan bahwa dalam model regresi ini tidak terjadi heteroskedastitas.

\section{Regresi Linier Berganda}

Perhitungan regresi linier berganda dibantu dengan menggunakan SPSS 23.0 for Windows adalah sebagai berikut :

Analisis Regresi Linier Berganda Coefficients $^{\mathrm{a}}$

\begin{tabular}{|c|c|c|c|c|c|}
\hline \multirow[b]{2}{*}{ Model } & \multicolumn{2}{|c|}{$\begin{array}{l}\text { Unstandardized } \\
\text { Coefficients }\end{array}$} & \multirow{2}{*}{\begin{tabular}{|l} 
Standardized \\
Coefficients \\
Beta \\
\end{tabular}} & \multirow[b]{2}{*}{ T } & \multirow[b]{2}{*}{ Sig. } \\
\hline & $B$ & Std. Error & & & \\
\hline $\begin{array}{ll}1 & \text { (Constant) } \\
& \text { EPS } \\
\text { DPS }\end{array}$ & $\begin{array}{l}-662,912 \\
7,026 \\
35,750\end{array}$ & $\begin{array}{l}302,987 \\
2,020 \\
9,193\end{array}$ & $\begin{array}{l}.514 \\
575\end{array}$ & $\begin{array}{l}-2,188 \\
3,478 \\
3,889\end{array}$ & $\begin{array}{l}, 056 \\
, 007 \\
.004\end{array}$ \\
\hline
\end{tabular}

a. Dependent Variable: Harga_Saham

Dari tabel coefficients diatas, maka dapat diperoleh persamaan regresi sebagai berikut: Persamaan linier berganda diatas adalah mempunyai interpretasi sebagai berikut :

$$
Y=-662,912+7,026 X_{1}+35,750 X_{2}
$$

1) Konstanta sebesar $-662,912$ menunjukkan bahwa jika perubahan variabel EPS dan DPS konstan atau bernilai nol (EPS dan DPS $=0$ ), maka harga sahamnya adalah sebesar $-662,912$.

2) Variabel EPS memiliki koefisien bertanda positif sebesar 7,026, hal ini berarti bahwa apabila terjadi perubahan EPS sebesar 1 satuan dengan asumsi variabel lainnya tetap, maka harga saham akan mengalami perubahan sebesar 7,026 dengan arah yang sama atau searah.

3) Variabel DPS memiliki koefisien bertanda positif sebesar 35,750 , hal ini berarti bahwa apabila terjadi perubahan DPS sebesar 1 satuan dengan asumsi variabel lainnya tetap, maka harga saham akan mengalami perubahan sebesar 35,750 dengan arah yang sama atau searah. 


\section{Uji Signifikansi Simultan (Uji F)}

Uji F digunakan untuk mengetahui pengaruh variabel independen yang terdiri dari Earning Per Share (EPS) dan Dividend Per Share (DPS) secara bersama-sama (simultan) terhadap variabel dependen yaitu Harga Saham. Berikut ini adalah hasil dari pengujian uji signifikansi simultan (uji F) :

ANOVA $^{\mathrm{a}}$

\section{Hasil Uji F}

\begin{tabular}{|ll|l|l|l|l|l|}
\hline Model & Sum of Squares & df & Mean Square & $\mathrm{F}$ & Sig. \\
\hline 1 & Regression & 8032167,727 & 2 & 4016083,863 & 22,920 &, $000^{\mathrm{b}}$ \\
& $\begin{array}{l}\text { Residual } \\
\text { Total }\end{array}$ & 1576988,523 & 9 & 175220,947 & & \\
\hline
\end{tabular}

a. Dependent Variable: Harga_Saham

b. Predictors: (Constant), DPS, EPS

Sumber : Data diolah menggunakan SPSS 23, 2016.

Berdasarkan hasil pengujian ANOVA diatas dapat dilihat bahwa nilai $\mathrm{F}_{\text {hitung }}$ sebesar 22,920 , sedangkan $\mathrm{F}_{\text {tabel }}$ dengan tingkat signifikansi $5 \%$ dan derajat pembilang $(\mathrm{df} 1)=\mathrm{k}-1=3-1=2$, derajat penyebut $(\mathrm{df} 2)=\mathrm{n}-\mathrm{k}=10-3=7$, diperoleh $\mathrm{F}_{\text {tabel }}$ sebesar 4,74. Dengan melakukan perbandingan, di mana $F_{\text {hitung }}(22,920)>F_{\text {tabel }}(4,74)$ dan nilai signifikansi $0,000<0,05$, sehingga $\mathrm{Ho}_{3}$ ditolak dan $\mathrm{Ha}_{3}$ diterima. Hal ini dapat disimpulkan bahwa terdapat pengaruh yang signifikan antara Earning per Share (EPS) dan Dividend Per Share (DPS) secara simultan terhadap Harga Saham.

\section{F. Kesimpulan}

Berdasarkan penelitian yang telah dilakukan sebelumnya serta hasi analisis yang telah dijelaskan pada bab-bab sebelumnya, maka dapat ditarik kesimpulan sebagai berikut:

1. Perputaran piutang berpengaruh positif tetapi tidak signifikan terhadap profitabilitas pada perusahaan manufaktur sektor industri barang konsumsi yang terdaftar di Bursa Efek Indonesia periode 2013-2015.

2. Perputaran persediaan berpengaruh positif dan signifikan terhadap profitabilitas pada perusahaan manufaktur sektor industri barang konsumsi yang terdaftar di Bursa Efek Indonesia periode 2013-2015.

3. Rasio Lancar berpengaruh positif tetapi signifikan terhadap profitabilitas pada perusahaan manufaktur sektor industri barang konsumsi yang terdaftar di Bursa Efek Indonesia periode 2013-2015.

\section{G. Daftar Pustaka}

Agnes, Sawir. 2009. Analisis Kinerja Keuangan dan Perencanaan Keuangan Perusahaan. Jakarta Penerbit : Gramedia Pustaka Utama

Ambarwati, Sri Dwi Ari, 2011. Manajemen Keuangan Lanjutan. Edisi Pertama. Yogyakarta: Graha Ilmu

Bramasto, 2008. Dasar-dasar Manajemen Modal Kerja. Edisi Pertama. Jakarta: Rineka Cipta

Brigham, F.Eugene dan Houston, Joel F. 2006. Dasar-dasar Manajemen Keuangan Edisi 10. Jakarta: Salemba Empat.

Djarwanto, 2004. Pokok-Pokok Analisa Laporan Keuangan, Edisi kedua, Yogyakarta Badan Penerbit : Fakultas Ekonomi 
Ghazali, Imam, 2016, "Aplikasi Analisis Multivariat Dengan Program IBM SPSS 23”, Cetakan kedelapan, Universitas Diponegoro, Semarang. Hal 5, 103, 134, 138, 156, 157.

Hanafi Mamduh dan Halim Abdul, 2014, Analisis Laporan Keuangan, cetakan pertama, Edisi keempat, Yogyakarta Penerbit : UPP STIM YKPN.

Harjito, A. dan Martono. 2014. Manajemen Keuangan. Edisi Kedua. EKONISIA. Yogyakarta.

http://www.idx.co.id/Bursa Efek Indonesia/Daftar Perusahaan Manufaktur BEI Tahun 2013

Irawati, Susan, 2006. "Dasar-dasar Manajemen Keuangan” Cetakan Kesatu. PT.Pustaka: Bandung

Kasmir, 2013, Analisis Laporan Keuangan, edisi pertama, cetakan keenam, Jakarta Penerbit : Rajawali Pers.

Martono. 2014. Manajemen Keuangan. Edisi Kedua. EKONISIA. Yogyakarta.

Muhammad Kamel, 2010. Analisis Pengaruh Kebijakan Modal Kerja Terhadap Profitabilitas Pada Perusahaan Rokok Yang Go-Publik di Indonesia. Skripsi Universitas Negeri Medan, Sumatera Utara.

Munawir, 2004. Analisa Sumber Dan Penggunaan Modal Kerja. Edisi Keempat. Liberty: Yogyakarta

Mulyaningsih, S. 2015. "Pengaruh Perputaran Kas, Perputaran Piutang dan Perputaran Persediaan terhadap Profitabilitas pada Perusahaan Food \& Beverages." Skripsi. Sekolah Tinggi Ilmu Ekonomi Indonesia (STIESIA). Surabaya

Putra, Lutfi Jaya. 2012. "Pengaruh Perputaran Modal Kerja Terhadap Profitabilitas (Studi Kasus : PT. Indofood Sukses Makmur Tbk.)". Jurnal Ekonomi Gunadarma, Vol. 9. No. 1, hal. $1-10$.

Priyatno, Duwi, 2013, "Mandiri Belajar Analisis Data Dengan SPSS", Yogyakarta: Media Kom. Hal 9, 30, 40.

Priyatno, Duwi, 2014, "SPSS 22 Pengolah Data Terpraktis", Edisi 1, Yogyakarta: ANDI.

Hal: 94, 103, 106.Santoso, Singgih, 2013, "Menguasai SPSS 21 di Era Informasi". PT.ELEK Media Komputindo. Jakarta. Hal: 347, 354

Riyanto, Bambang, 2011. Dasar-Dasar Pembelanjaan Perusahaan, Edisi Keempat, Cetakan Ketujuh, Yogyakarta BPFE.

Satriya, Dian dan Vivi Lestari. 2014. "Pengaruh Perputaran Modal Kerja Terhadap Profitabilitas Perusahaan." E-Jurnal Manajemen Universitas Udayana, 3(12) : pp : 1927-1942

Singh, J. P \& Shishir Pandey 2008. Impact of Working Capital Management in The Profitability of Hindalco Industries Limited Pharmaceutical Sector. The IcfaiUniversity Journal of Financial Economics, 6(4).

Suharso, 2009. Metode Penelitian Kuantitatif Untuk Bisnis. Cetakan Pertama. Penerbit PT Indeks: Jakarta

Sugiyono, 2008. Metode Penelitian Kuantitatif, Kualitatif, R\&D. Penerbit: Alfabeta, Bandung

Sutrisno, 2009. Manajemen Keuangan Teori, Konsep dan Aplikasi. Edisi Pertama Cetakan Ketujuh. Penerbit Ekonsia: Yogyakart 